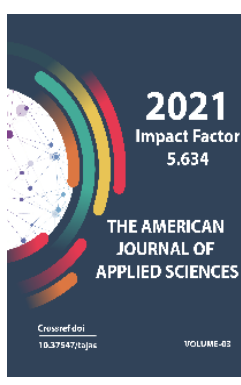

Journal Website: http://usajournalshub.c om/index,php/tajas

Copyright: Original content from this work may be used under the terms of the creative commons attributes 4.0 licence.

\section{Species Composition And Areal Of Distribution Of Bronze Beetles (Cetoniinae) In Orchards In The Conditions Of Uzbekistan}

Umurzokov M.R.

Master Student, Tashkent State Agrarian University, Uzbekistan

Turgunboeva D.

Master Student, Tashkent State Agrarian University, Uzbekistan

Khudoyqulov A.M.

Doctor Of Agricultural Sciences, Associate Professor, Tashkent State Agrarian University, Uzbekistan

Omanturdiyev Sh.S.

Phytopathologist Agronomist Position In The Association Of Walnut Producers And

Exporters, Uzbekistan

\title{
ABSTRACT
}

This article, using the literature, analyzes the species composition, distribution, harmfulness, bioecology of beetles belonging to the family of bronze beetles (Cetoniinae) of the order Coleoptera in orchards. Based on the information received, practical conclusions and recommendations are presented.

\section{KEYWORDS}

Orchard, bronze beetle, generative organs, furry deer, fringed deer, agrotechnical method, chemical method.

\section{INTRODUCTION}

The countries of the United States and Turkey from European countries occupy leading positions in the cultivation and export of fruit and vegetable crops in the world, the countries of China and Iran from the Asian continent are achieving high results. However, 
there was a lot of precipitation, and losses under the influence of pests and diseases formed up to $90.0 \%$ in apple orchards in years when the air temperature is low and the humidity is high $[1 ; 2]$.

The demand for fruits and vegetables, which is considered the main source of food not only in Uzbekistan, but throughout the world, is growing today. And this requires the cultivation of quality products, the adoption of measures to combat diseases and pests that pose a threat to the vegetables and fruits grown annually [1; 28-31-p.].

Fruit gardens of our republic are damaged by many sucking and gnawing pests (aphids, scale insects, spider mites, apple moth, Asian moth, bugs) and by representatives of the order of beetles [3; 260-261-p.].

In subsequent years, in orchards, the harm from species belonging to the subfamily of the family of bronze beetles (Cetoniinae) of the order Coleoptera increases significantly. In particular, bronze beetles (Cetoniinae) from representatives of the subspecies furry deer (Tropinota (Epicometis) hirtiformis Reitter) beetle, Turanian deer (Tropinota (Epicometis) turanica reitter), bordered deer (Oxythyrea cinctella), feed on by the organisms of Schaum. foothill areas causing great damage. Causes serious damage to the crop up to 30$60 \%$, depending on the amount of damage caused by the pest as a result of favorable or unfavorable weather conditions in the spring of the year, as well as the quality of the remaining fruits. [2; 30-302-p.].

Beetles in early spring, first on weeds, then from fruit orchards (apple, peach, quince, pear, cherry, etc.) damage the generative organs of trees. In addition, some types of bronze beetles are harmful by feeding on the flower formations of cultivated flowering plants. Before developing an improved system for combating damage to unwanted species of the young family of bronze beetles (Cetoniinae), it is necessary to study their species composition and distribution area.

In Central Asia, you can find mainly three species: furry deer (Tropinota (Epicometis) hirtiformis Reitter), Turanian deer (Tropinota (Epicometis) turanica Reitter), fringed deer (Oxythyrea cinctella Schaum.) Cause great harm by eating flowers.

Since the climatic conditions of the geographic region of Central Asia are dry and continental, these pests are considered harbingers of their spread and spread.

The above pests are described below.

Shaggy deer (Tropinota (Epicometis) hirtiformis Reitter), beetle length 9,0-11,7 mm, width up to $5,8-6,8 \mathrm{~mm}$, beetle color is black, body is long, beetle looks brownish due to low furry. The bronze Turon beetle walks along a set of winding paths across the white from the chitinized wing. The larva of the furry deer is covered with hairiness up to $35 \mathrm{~mm}$ with a thin curved length; differs in the presence of 3 pairs of legs in the chest.

Turanian deer (Tropinota (epicometis) turanica Reitter). the body length of the beetle is $10-13.2 \mathrm{~mm}$, the width is up to $8 \mathrm{~mm}$, the color is black, but visible as brown. The very larva of the Turonian bronze beetle up to $38 \mathrm{~mm}$ long is covered with hairs; there are white stripes around the airways that spread as light.

Fawn bordered (Oxythyrea cinctella Schaum.), The beetle is $8-11 \mathrm{~mm}$ long, has a black color, shines; along the front lateral edges of the 
back there is a narrow flowing path, along the adjacent edge of the back there are two white dots. Too many small specks seeping into the wing are located; the point is that these spots are located on the edge of the correspondence of the wingspan to the larger one, the wingspan located at the top. In winter, whitish spots also appear on the leg and chest. There are two prongs at the tip of the foreleg. The $20 \mathrm{~mm}$ larva is similar to the larvae of other beetle species. [2; 300-302-p., 4; 102-103-p. five; S. 88-102.].

Bronze beetles fly from mid-March to mid-tolate May after maturation. The Bronze Beetle flies off the ground, causing more damage to the lower branches of trees and stunted flowers. After mating the bronze beetle, the female lays eggs, trapped between humus and nutrient-rich soil. Up to two weeks after oviposition, the larvae emerge. Bronze beetle larvae feed on decaying organic matter and are harmless; until autumn, they envelop a cocoon of soil or manure and turn into a pupa. Bronze beetles breed once a year.

Findings. According to the results of the studies carried out, when fighting bronze beetles in orchards, it is necessary to carry out preventive measures in a timely manner, taking into account their bioecology and life expectancy. According to these data, using effective chemical, biological and agrotechnical means, they are considered an important factor in the management of their numbers. High biological efficiency can be achieved when using chemicals Mospilan 20\% d.p. (0,2 I / ha), Confidor k.s. (0,3 I / ha) against beetles.

Many believe that the thick, gray-white larva nibbles at the roots of plants. This, unfortunately, is true. Only it does not concern the larva of the bronze beetle, but the larva of the crunch, which at first glance looks exactly the same. The larva of the bronze beetle feeds only on detritus of plant origin - dead, not decomposed plant remains. That is why they were interested in the old logs of our house as a habitat. Living plant tissues, for example, roots, are not at all attractive to them. What can not be said about the larvae of the crunch (May beetle).

Moreover, without harming the plants, the voracious larva of the bronzer brings quite tangible benefits. It feeds continuously during its existence, crushing plant remains already partially destroyed by rotting with its jaws, contributing to the rapid decomposition of solid particles that would have remained intact for a long time.

Speaking in defense of the larva of the bronzer, it should be said, for the sake of justice, that the imago of the bronzer is an adult insect, it feeds by gnawing out the stamens and petals of flowers, young leaves, and also eating fruits. However, the bronze does not cause serious damage to fruit and flower growing. No special methods have even been developed to control this insect.

The bronze bird can be considered a safe insect for agriculture, given the peculiarities of its life. The life story of the insect was surprisingly described by the French entomologist Jean-Henri Fabre.

Bronze has a two-year development cycle. The beetle emerges from the pupa in mid-summerin July. Until the end of summer, the insect actively feeds, devoting all its time to food. But beetles are only interested in fruits, eating overripe fruits and berries in large quantities. 
Bronzes are thermophilic and light-loving. Therefore, they are active only on a hot sunny day, in cloudy weather and at the slightest cold snap, hiding in a shelter. With the onset of cool time, the beetles take shelter for the winter. Coming out of the state of torpor in the spring, the bronzes again begin to feed, but much less actively than last year after their hatching. Since there are no berries or fruits at this time, the insects feed on flowers, young leaves and the resulting sap of trees. Bronzes love warmth, so they wake up from hibernation when it's already hot enough. At this time, the fruit trees are already mostly fading. Bronzes most often feed on rosehips (though not forgetting about roses), on the inflorescences of snyti and meadowsweet.

Then the insects mate, and the female lays her eggs in the humus-rich soil, compost heaps, dead leaves, and sawdust. After the breeding stage, the bronzes are no longer interested in food: until autumn, adults fly sluggishly, crawl, and with the onset of cold weather crawl into the soil, where they end their lives. At this time, twelve days after the female lays the eggs, small larvae hatch and begin to destroy the rotting remains of plants in huge quantities, turning them into a nutrient for new plants. The larva moves in the soil, passing through its intestines plant remains, using for movement not short legs, too weak for such a bulky body, but powerful rollers on the back. The larva of the bronzer, if it is placed on the surface with its belly down, turns its legs up and begins to crawl on its back. The legs of the insect larva are used only when it is time to create a cocoon, inside which the larva turns into a pupa, from which the adult insect — the bronze beetle-will later emerge.
A rare species whose population is declining. Brief description. The length of the body is 22$28 \mathrm{~mm}$. The body is somewhat flattenedrolled, with a pronounced metallic-shiny tint of ochre-greenish or copper-red tint on top, and a pale greenish-golden tint on top. The underparts and legs are intensely green, sometimes with a pale blue body. The elytra are uniformly convex with faint punctuation, but without any patterns. The lateral parts of the middle breast are visible from above from under the elytra. The elytra themselves are on the sides with a notch in the lower shoulder part.

Limiting factors. Prolonged dry weather during the growing season. Chemical treatment of forest and fruit and berry crops (primarily in gardens near the forest) in the spring-summer period (May-June). Thinning of forests, continuous and concentrated logging with uprooting and hauling of wood; reduction of old deciduous stands, especially oak forests; removal of dead wood; clearing of forests. Recreation, including the activities of mushroom pickers. All factors are most significant for beetle larvae.

Security measures. The species of green bronze is included in the Red Books of the Republic of Tatarstan and the Ulyanovsk Region (2). Special protection measures have not been developed. Based on the biology and ecology of the species, we consider the following approaches to ensure its preservation and reproduction appropriate. It is necessary to stop the practice of allotting land for horticultural societies in the nearforest part of the forest. Within the habitat of the species, stop any chemical treatments both in the forests and in the gardens adjacent to these places, especially in MayJune, as well as in farmland. Artificial 
maintenance and breeding is possible, which requires special technological research and in terms of preparing the food substrate for the larvae [4].

\section{REFERENCES}

1. Кимсанбоев Х.Х., Болтаев Б.С., Сулаймонов Б.А. -"Интегрированные меры борьбы против вредителей сада”. Ташкент, 1998.

2. Яхонтов В.В. Вредители сельскохозяйственных культур Средней Азии и борьба с ними. Ташкент, 1962 й. 300-302 c.

3. Хўжаев Ш.Т., Холмуродов Э.А. Энтомология, основы защиты сельскохозяйственных культур и агротоксикологии. Ташкент. “Фан” нашриёти, 2019 й. 260-261 с.

4. Мухаммадиев Б.Қ., Холмуродов Э.А. “Экология насекомых и систематический анализ видового состава". Ташкент-2015. 102-103 с.

5. Медведев С. И. Пластинчатоусые (Scarabaeidae). Подсемейство Cetoninae, Valginae / С. И. Медведев // Фауна СССР. Жестокрылые. - 1964. - Т. Х, Вып. 5. Мл С. 88-102.

6. Долженко В. И., Долженко Т. В. Биологическая эффективность и разложение остаточных количеств инсектоакарицидов на основе абамектинав саду // Плодоводство и ягодоводство России. - 2014. - Т. 40. №. 1. - C. 104-107.

7. K. Rataj, Zlatohlavkoviti (Cetonidae) V. Dil, Cetoniini, Druhy palearkticke oblasti. 1998.

$-175 \mathrm{c}$.

\section{Internet sites}

1. http://www.fao.org/faostat
2. https://www.botanichka.ru/article/bol ezni-i-vrediteli-na-yablonyah

3. https://www.gbif.org

4. https://ikobrin.ru/ 